\title{
The Community of the Book:
}

\section{A Bibliography}

by Rosemary H. Arneson

Our original idea in compiling a bibliography for this issue of North Carolina Libraries devoted to the Community of the Book was to present a selection of books and readings that celebrate the joys of reading. As we began the work of pulling these works together into one list, we soon realized that there were far more books on the subject than we could ever cover. Apparently, one common trait among the Community of the Book is that we love to talk about what we read!

We present here an eclectic assortment of readings about readings, from the historical to the futuristic, from the celebratory to the eulogistic. The common thread is that, for each author, books matter. We offer them to you as our way of continuing the Community of the Book.

Altick, Richard D. The English Common Reader: A Social History of the Mass Reading Public 1800-1900. Chicago: University of Chicago Press, 1957.

"The history of the mass reading audience," says Altick, "is , in fact, the history of English democracy seen from a new angle." With that sweeping claim, Altick takes on the task of tracing how the practice of reading developed in Great Britain in the nineteenth century. During that century, books and periodicals changed from publications for the elite to publications for the masses. That change took place against a backdrop of sweeping social and political upheaval. Altick examines those social and political trends and the impact they had on the business of books as well as on the practice of reading.

Birkerts, Sven. The Gutenberg Elegies: The Fate of Reading in an Electronic Age. Boston: Faber and Faber, 1994.

Birkerts loves books passionately. In an early chapter, called "The Paper Chase," he describes how this passion developed first into an ambition to write, then into book collecting as both hobby and profession, and finally into life as an essayist and critic. In the first part of the book, Birkerts sets out to think, deeply and critically, about the act of reading and the relationship that arises between reader and writer. In the second section, he looks at books and reading in the electronic age. And he is not optimistic about the future of the things he loves so well. Electronic communication, he contends, erodes our language by "dumbing down" our discourse. It flattens our historical perspective by shrouding the chronology of history and distorting our memories. Finally, Birkerts says, electronic communication turns us from private beings into collective ones. Birkerts concludes with three meditations in which he ties the first two parts of the book together and attempts to look ahead to the future of books and reading.

Canfora, Luciano. The Vanished Library: A Wonder of the Ancient World. Translated by Martin Ryle. Berkeley: University of California Press, 1987.

In Alexandria, the ruler Ptolemy II and his successors sought to build a library that housed a copy of all the books in the known world. Each book was to be translated into Greek so that these conquerors could come to some understanding of the peoples and cultures they had conquered and now hoped to rule. According to Canfora, this library was the nucleus of the extended community of the empire. Canfora reminds us that libraries, as the repositories of our culture, help people of vastly different cultures to understand each other. Libraries are precious things that, if destroyed, cannot ever be truly replaced.

Clutton-Brock, Arthur. Essays on Literature and Life. Essay Index Reprint Series. Freeport, NY: Books for Libraries Press, 1927, reprinted 1968.

Evelyn Clutton-Brock, widow of the author of these essays, brought together sixteen of her husband's contributions to the Times Literary Supplement and the London Mercury. 
These essays are works of literary criticism from the 1920s. The essay, "The Pleasure of Reading Biographies" (pp. 137-154) speaks of the affection that arises between subject and reader through the good work of an honest biographer. Clutton-Brock is writing specifically about Modeste Tchaikovsky's biography of his brother. Clutton-Brock describes an intimate connection, facilitated by the biographer, and broadens it to include one with the society and culture of the subject of the biography. He raises the possibility that we readers seek this connection because we cannot achieve the same kind of intimacy with the people around us and must, therefore, search for substitutes through books, but goes on to assert that in literature we seek, and sometimes find, the beauty that eludes us in life.

Hart, James D. The Popular Book: A History of America's Literary Taste. Berkeley: University of California Press, 1961.

There is, Hart says, some "accounting for taste" (p. 283). In this book, he seeks to understand how America's preferences in popular reading were influenced by contemporary pressures. What societal need did books meet at the time they became popular? How did the authors of these popular works express the sentiments of the American people? These are the questions Hart seeks to answer, and in doing so, he provides a close examination of American social history.

Laskin, David. A Common Life: Four Generations of American Literary Friendship and Influence. New York: Simon \& Schuster, 1994.

Laskin examines four pairs of authors: Hawthorne and Melville, James and Wharton, Porter and Welty, and Bishop and Lowell. Their friendships shaped the individual works of each author, and in so doing, shaped American literature. Laskin goes beyond simply chronicling the development of each literary friendship. He seeks to discover the bond between the authors, including the bond of nationality. He looks at the works of each author to uncover the "story patterns," a phrase he takes from Welty, that mirror the minds and hearts of the writers.

Mills, Gordon. Hamlet's Castle: The Study of Literature as a Social Experience. Austin: University of Texas Press, 1976.

Mills drew the title of this book from Werner Heisenberg's Physics and Beyond, in which Heisenberg describes a visit to Kronberg Castle with Niels Bohr. According to Heisenberg, Bohr commented as they walked around the castle, "Isn't it strange how this castle changes as soon as one imagines that Hamlet lived here?" Mills develops that idea as he examines how an individual's experience with the illusion created by literature can influence and change another's experience with the same illusion.

Morrow, Lance. "The Best Refuge for Insomniacs," Time 137 (April 29, 1991): 82.

What book do you pick up at three in the morning? What are the "rafts [you] cling to in bad weather?" In this brief essay, Morrow examines the books we turn to when we need to grab hold of sanity, during the dark hours of sleepless nights when the troubles of our lives loom largest. Morrow's claim is that there are particular books we turn to for help, books that speak to us in some way that remind us that we are not alone. For Morrow, these are the works of Samuel Johnson, the Book of Job, and Wind in the Willows, among others. At three in the morning, we reach for books that will reassure us that we are still connected with others, that we are not alone, that we are a part of the Community of the Book.

Moss, Elaine. Part of the Pattern: A Personal Journey through the World of Children's Books, 1960-1985. New York: Greenwillow Books, 1986.

As a freelance writer, a contributor to Signal and other journals, and as a commentator for the BBC, Moss devoted her adult life to reading and writing about children's literature. This volume collects together a selection of her reviews, essays, interviews, and broadcasts spanning twenty-five years. Read together, they constitute a celebration of children's literature and of reading. Her essay "A Sense of Community: Zen and the Art of Librarianship" describes the relationship that is built between the librarian and the reader as children begin to explore books. Moss cautions against the rush of technology if it threatens that human relationship.

Mott, Frank Luther. Golden Multitudes: The Story of Best Sellers in the United States.

New York: R. R. Bowker, 1947.

What do The Day of Doom by Michael Wigglesworth (1662), Silas Marner by George Eliot 
(1861), and The Pocket Book of Boners (1941) have in common? All were, according to Mott, best sellers in their time. By examining which books enjoyed total sales equal to one percent of the population at any point in American history, Mott traces the development of American popular culture. Each best-selling book provides for Mott a window through which we can view American social history.

Peterson, Carla L. The Determined Reader: Gender and Culture in the Novel from Napoleon to Victoria. New Brunswick, NJ: Rutgers University Press, 1986.

Peterson looks at nine literary characters taken from nineteenth century French and English novels. Reading is an important activity for each of these characters, and she seeks to discover how each protagonist's reading shapes his or her life. Peterson carries her study further to examine how each author's depiction of a reader-protagonist reflects the novelist's attitude toward books. She combines literary scholarship with an historical perspective to examine the role books played in the lives of nineteenth century British and French culture.

Rubin, Joan Shelley. The Making of Middlebrow Culture.

Chapel Hill: University of North Carolina Press, 1992.

During the first half of the twentieth century, America experienced a tremendous upsurge of interest in reading and in books. Book clubs flourished across the nation; the Book of the Month Club, founded in 1926, sought to bring books to a wider readership; the emerging medium of radio gave critics such as Alexander Woollcott and William Lyon Phelps a new venue for their work. To some, this popularization of books and reading among the middle class was benign. To others, including Virginia Woolf, it was a "corruption of taste by commercial interests" (p. xiii). Rubin examines the phenomenon of the rise of American middlebrow culture and the arguments that surrounded it. She focuses on five aspects: the popularity of "outline" books such as Will Durant's The Story of Philosophy, the impact of literary programming on the radio, the founding of the Book of the Month Club, the emergence of "great books" programs around the country, and the introduction of the New York Herald Tribune's book review section. She combines excellent scholarship with an examination of the lives of the people behind this movement to make an extraordinarily readable book.

Smith, Hal H. On the Gathering of a Library. Privately printed, 1943.

Smith wrote this book for the person who wants to develop a personal collection of books that is "gathered" according to some plan, but with room left in that plan for some variance. He is not writing for the person who looks on books as decorative objects to fill a room, but for the person who loves books with a consuming passion. While Smith mentions personal favorites, and recommends certain books to his readers, he encourages the reader to pursue personal interests. He concludes by pointing out that the book collection gathered throughout a lifetime will, after one's death, be dispersed, but that, in time, the books will find their way into other collections and thus live on.

Walpole, Hugh. Reading: An Essay. New York: Harper \& Brothers, 1927.

Sir Hugh Walpole begins this small volume by telling the story of his reading Alice in Wonderland as a child. Alice, he says, is stupider than he would have been if he had found himself in her situation, and he confesses to relishing the predicaments into which Carroll puts her. Walpole cites Alice as the book that showed him "another world to play in" (p. 8). He wrote this book at a time when many others were listing - or better, prescribing-Great Books that a person should read. Walpole takes a different tack: Reading, he says, is fun. In books, a reader can find the same delight he felt when he imagined the Queen taking off Alice's head.

West, James L.W., III. American Authors and the Literary Marketplace Since 1900. Philadelphia: University of Pennsylvania Press, 1988.

Authorship in the twentieth century is, as perhaps never before, a commercial proposition. In this volume, West explores the relationship between the commerce of publishing and the art of writing. He focuses primarily on novelists, short story writers, and poets, specifically what he calls the "public" author. West defines the public author as a serious writer whose work appeals to a large audience and who is thus able to earn a living by writing. These authors became "public" not solely by the merit of their works but through the efforts of the publishing industry. 